\title{
BUSINESS PROCESSES OPTIMIZATION WITHIN UKRAINIAN AUTOMOBILE ENTERPRISES IN TERMS OF EU ENTERING PERIOD
}

\author{
Oleksandr PIDMURNIAK'1, Lyudmila ANISIMOVA² \\ Taras Shevchenko National University of Kyiv, Ukraine
}

\begin{abstract}
The purpose of the paper is to summarize and present the most common principles and management methods to seek the most efficient and profitable exit way for automobile enterprises during the period of economic recovery in Ukraine. In the course of the research, we have analysed what is SOA (Service Oriented Architecture) and advantages of its implementation, the differences between BPMs and IBPMs (Intelligent Business Process Management Suite) and other. Methodology. The survey is based on a comparison of different business and management approaches whereby the efficiency of business process sufficiently increases. In total, more than 30 methods are precisely analysed, around 15 most frequent management systems considered, which led us to identify 5 main recommendations. Results of the survey showed that Ukraine has very ignorant social and political environment, human capital is undeveloped and less meritocratic than our neighbours in EU have. A shortage in domestic car manufacturing, lack of new plants and technologies, as the resulting amount of workplaces remains the same or going down because of emigration, all that conduce to the growth of a number of imported cars. Trying to recognize the most recent threatens, we have detected there are no government programs, grants, laboratories, and science-plants for the young generation. Practical implications. Since Ukraine become in war, the economic and political crisis, downturn with national currency etc., domestic households faced with the huge amount of problems: inflation, collapsing currency rate, political uncertainty. All of that drives domestic business to a corner, where the growth of management efficiency and organizational transformation were the only way out. Value/originality. An Agile is a method when the company's management comes in touch with the latest business process optimization Apps like IBM, SoftwareAG, Pegasystems.
\end{abstract}

Key words: business process, automobile, enterprise, optimization, economic recovery, management.

JEL Classification: L22, M12-14, O20-40

\section{Introduction}

Being struggled as much as confused with current economic and political situation Ukrainian business has faced off with the situation, which has no precedent in the past. In this paper, we will try to build recommendations and offerings for domestic automobile enterprises to achieve business process improvement by embedding existing tools and opportunities for business optimization.

Facing the wide scale commoditization of goods and services, today's business leaders are turning to process improvements to differentiate from competitors. Optimizing outdated processes help organizations reduce costs, increase efficiency, enhance customer service, make smarter decisions from better data, minimize risk, adapt more quickly to regulatory change, and strengthen compliance (KPMG, 2016)
As the world becomes more diversified and a number of tools and methods simultaneously with problems and issues grow rapidly, the solutions for resolving problems are increasing also. Business process management provides organizations with their continuous improvement and optimization. There are a wide variety of process management tools, approaches, and methods, which have been built up to improve business processes. In modern process management, there are two conceptual approaches to improve business processes:

1) gradually (step by step) approach to process improvement (in Deming) within the existing organizational management structure that requires minor investments or do not need them at all;

2) cardinal (fundamental) approach (by Hammer and Champy), leading to significant changes in the process

\footnotetext{
Corresponding author:

${ }^{1}$ Department of Management of Organization and Administration, Taras Shevchenko National University of Kyiv.

E-mail: opidmurnyak@gmail.com

${ }^{2}$ Department of Management of Innovative and Investment Activity, Taras Shevchenko National University of Kyiv.

E-mail: lyuda231@ukr.net
} 
and fundamental changes in the organizational structure of management.

\section{Management tools, approaches and methods}

Considering gradually approach, we would like to begin with an agile approach, which is a very highusage tool, therefore, we will try to look at this tool more precisely.

The term agile (flexible, dynamic) appeared in 2001 with a manifesto, in which people, product, and readiness for change were placed above coordination, paperwork, and the original plan. But the organizations that worked on this principle arose in the 60 s of the 20 th century, and without even suspecting that they were agile. Now agile is associated primarily with software development, with advanced technologies. In fact, agile organizations can be found in different areas, and the pioneers of this approach met in completely unexpected areas.

In the 60s in the US, there was such a pilot, military strategist John Boyd. He came up with the theory of OODA, according to which the aerial combat wins not the best aircraft in terms of technology but the pilot, who takes the maximum number of decisions for a certain period of time and instantly reacts to changing circumstances. In general, the fastest and the most flexible thinker win. Boyd's theory was actively used in those times in the military sphere. But this is just one of many episodes showing where agile was in demand.

Agile is an umbrella concept (when it is needed), and not a specific technology or any specific solution. This concept combines many different methods and approaches, which together make the organization different. The core of agile, its main component, is a small team. And there is a clear scientific justification for its optimal size - from six to twelve people. The team should be cross-functional and include people of different specializations: product producers, marketers, lawyers, designers, IT professionals, and so on. They all form a single organism and ideally should work in the same room. Be a holistic mechanism that controls the rest of the process.

In large organizations, there are many tasks and products that you need to work on at the same time. Therefore, the whole team is divided into many small teams - sometimes tens or even hundreds. They, in turn, are united in so-called "tribes". The number of teams that can form a "tribe" is limited to ten, a maximum of twenty. As a result, each of the large groups includes up to a hundred or two hundred people. This is also a scientifically based number: while using it, you can still maintain social connections without sacrificing work.
Agile and flexible business processes workflow architecture plays an important role in the success of any enterprise. In the new era, most of the processes are automated and they are supported by IT-Services in the form of service-oriented architecture (SOA) components. Due to mobility and scalability, as well as high-performance computing and distributed working environment, it is crucial to focus on an architecture, which is agile, optimized, cost-effective, and easy to implement. The main contribution of the research study is to propose an agile, cost-effective, and scalable solution framework (Research Publish, 2016).

A business process (BP) is a set of many business activities within the organizational environment or outside organizations achieving a business goal (Weske, 2012). SOA is a business-driven architectural model of IT services and business process management (BPM) services are usually supported and operated through IT infrastructure (Liu, Yang 2008). Modelling workflows based on IT services make more sense as they are supported by IT technologies and they can be easily reengineered or modified (Matjaz, 2008). BPM and SOA combination helps business process experts to make agile, flexible and easy to implement architecture fulfilling their strategic goals (Brunswick, 2008).

Intelligent business process management suites provide real-time insights to achieve better business outcomes and help business transformation leaders, business process directors, and solution architects improve business outcomes through the process reinvention and transformation.

The intelligent business process management suite (iBPMS) market is the natural evolution of the earlier business process management suite (BPMS) market, adding more capabilities for a greater intelligence within business processes. Capabilities such as validation (process simulation, including "what if") and verification (logical compliance), optimization, and the ability to gain insight into process performance have been included in many BPMS offerings for several years. IBPMSs have added enhanced support for human collaboration such as integration with social media, mobileenabled process tasks, streaming analytics and realtime decision management. For a more detailed description of business process management (BPM) platforms, see "Select the Right Type of BPM Platform to Achieve Your Application Development, Business Transformation or Digital Business Goals." For a more detailed description of technologies that help make processes more intelligent, see "Practical Ways to Make Business Operations More Intelligent" (Gartner, 2016).

Nine capabilities that differentiate products within the iBPMS market are indicated below. 


\begin{tabular}{|c|c|}
\hline Type of capability & Meaning of capability \\
\hline Interaction Management & $\begin{array}{l}\text { The ability to orchestrate multiple types of activities and interactions at runtime to support the work } \\
\text { that people, systems, and "things" (as in the IoT) do to produce specific business outcomes. }\end{array}$ \\
\hline High-Productivity App Authoring & $\begin{array}{l}\text { Enables citizen and IT developers to quickly and easily build a process-centric application. } \\
\text { Applications built on the platform use a metadata model to manage the complete lifecycle of } \\
\text { business processes and manipulate data related to the process. }\end{array}$ \\
\hline Monitoring and Business Alignment & $\begin{array}{l}\text { iBPMS platform's support of business activity monitoring (BAM) to continuously track the state of } \\
\text { process instances, cases and other behaviours in near real time. }\end{array}$ \\
\hline Rules and Decision Management & $\begin{array}{l}\text { Software facilities - such as inference engines, recommendation engines, and decision management } \\
\text { capabilities - that provide guidance for making human or automated operational decisions according } \\
\text { to business directives or policy statements. }\end{array}$ \\
\hline Analytics & $\begin{array}{l}\text { Applies logic and statistics to data to provide insights for making better decisions. An iBPMS may } \\
\text { incorporate or have connections to, predictive analytics such as scoring services or prescriptive } \\
\text { analytics such as optimization engines. }\end{array}$ \\
\hline Interoperability & $\begin{array}{l}\text { Interoperation with external application services and systems that an iBPMS' adapters and adapter } \\
\text { development tools enable. Such services and systems include custom and commercial-off-the-shelf } \\
\text { packaged applications and cloud-based SaaS applications, and their databases. }\end{array}$ \\
\hline Intelligent Mobility & $\begin{array}{l}\text { The ability to access applications from a variety of mobile devices, including smartphones and } \\
\text { tablets. As well as providing access from anywhere, the platform optimizes the mobile device's native } \\
\text { capabilities, including its camera and other sensors. }\end{array}$ \\
\hline Process Discovery and Optimization & $\begin{array}{l}\text { The platform's capability that shortens the time it takes to discover and optimize behaviours (such } \\
\text { as processes, tasks, and policies) needed to improve business outcomes. This may include analysing } \\
\text { past execution history or simulating proposed behaviours. }\end{array}$ \\
\hline Context and Behaviour History & $\begin{array}{l}\text { iBPMS' maintenance of an archival history of events that have occurred during the interactions under } \\
\text { its control. The iBPMS may also manage other kinds of context data - from external applications, } \\
\text { databases or event streams - to enhance the intelligence and decisions made by the system. }\end{array}$ \\
\hline
\end{tabular}

Source: compiled by the author on the basis of (Gartner, 2016)

Factors affecting the activities of the company in modern conditions can be divided into external and internal. Let us explain the vision of these ones.

\section{External can be classified as:}

1. Dynamic development and stringent market requirements;

2. Expansion of the scope and objectives of the enterprise;

3. Requirements for the certification of quality management systems for a compliance with international standards of the ISO 9000: 2015 series.

\section{Internal can be classified as}

1. Increase in complexity and capital intensity of products or services;

2. Increasing the requirements for quality, quantity and range of products or services;

3. Reducing the life cycle of products or services;

4. Ineffective management system, including automating its support;

5. Imperfect technology of BP implementation and organizational structure;

6. Lack of standard solutions and methodological support.
The fundamental problem of management is the problem of complexity. In addition, it is important to recall that the head manages an enterprise as some kind of information model, therefore, an important aspect of management should be considered as the availability of prompt and adequate information about the managed facility.

The 1998 crisis forced Post-Soviet Union countries as well as Ukraine with its one of the most powerful production sector and prompted to rethink the conception of the market.

This led to the following production ideology:

- The simplest principle is confessed: "No sale - no business";

- Production is not considered strategically, i.e. gradual degradation of planning;

- In the field of quality, an emphasis is placed on procedures and rules that in practice do not lead to the desired results.

World experience shows that success is achieved by those firms that:

- Consider themselves as a single system, integrating such areas as marketing, creating new products, supplying, manufacturing, marketing, delivering products to the consumer, IT, and servicing;

- Used Industrial ERP standards to achieve technological efficiency as their main business model.

The discussion so far has looked at how individuals, groups, or organizations become skilful knowers, that is, move from unskilful knowing to skilful knowing within a 
process. The technology and personalization views provide contrasting ideas about how this is carried out. We will try to explain our vision of modern management processes with ISO. ISO International Standards ensure that products and services are safe, reliable, and of good quality. For business, they are strategic tools that reduce costs by minimizing waste and errors and increasing productivity.

ISO 9000:2015 describes the fundamental concepts and principles of quality management, which are universally applicable to the following below (ISO, 2017).
As well as ISO is one of the most respectful Organizations, which indicates the vision of future while countenancing what to assent and what does not, the main reason remains the same - to establish futureproof commitments for socially responsible companies. We should try to make purposes for everyone (in our case, it is employees) and create the enterprise where each will catch its professional and social destination.

We are living in an era where technology evolves and business goals are becoming dynamic. These goals are

\begin{tabular}{|l|l|}
\hline Quality Management Principles & \multicolumn{1}{c|}{ Rationale } \\
\hline Customer Focus & $\begin{array}{l}\text { Sustained success is achieved when an organization attracts and retains the confidence of customers } \\
\text { and other interested parties on whom it depends. Every aspect of customer interaction provides an } \\
\text { opportunity to create more value for the customer. Understanding current and future needs of customers } \\
\text { and other interested parties contribute to sustained success of an organization. }\end{array}$ \\
\hline Leadership & $\begin{array}{l}\text { Creation of the unity of purpose, direction, and engagement enable an organization to align its strategies, } \\
\text { policies, processes, and resources to achieve its objectives. }\end{array}$ \\
\hline Engagement of People & $\begin{array}{l}\text { To manage an organization effectively and efficiently, it is important to involve all people at all levels and } \\
\text { to respect them as individuals. Recognition, empowerment, and enhancement of skills and knowledge } \\
\text { facilitate the engagement of people in achieving the objectives of the organization. }\end{array}$ \\
\hline Improvement & $\begin{array}{l}\text { The quality management system is composed of interrelated processes. Understanding how results are } \\
\text { produced by this system, including all its processes, resources, controls, and interactions allows the } \\
\text { organization to optimize its performance. }\end{array}$ \\
\hline $\begin{array}{l}\text { Evidence-based Decision } \\
\text { Making. }\end{array}$ & $\begin{array}{l}\text { Improvement is essential for an organization to maintain current levels of performance, to react to } \\
\text { changes in its internal and external conditions, and to create new opportunities. }\end{array}$ \\
\hline Relationship Management & $\begin{array}{l}\text { Decision-making can be a complex process, and it always involves some uncertainty. It often involves } \\
\text { multiple types and sources of inputs, as well as their interpretation, which can be subjective. It is } \\
\text { important to understand cause and effect relationships and potential unintended consequences. Facts, } \\
\text { evidence, and data analysis lead to a greater objectivity and confidence in decisions made. }\end{array}$ \\
\hline $\begin{array}{l}\text { Interested parties influence the performance of an organization. Sustained success is more likely to be } \\
\text { achieved when an organization manages relationships with its interested parties to optimize their impact } \\
\text { on its performance. }\end{array}$ \\
\hline
\end{tabular}

Source: compiled by the author on the basis of (ISO, 2017)

\begin{tabular}{|c|c|}
\hline Management platforms & Short Description \\
\hline AgilePoint & $\begin{array}{l}\text { AgilePoint iBPMS is a Microsoft-centric platform that consists of an integrated core set of components } \\
\text { (AppBuilder, eForms Builder, Data Sources and Reports) used to create mission-critical business applications. } \\
\text { Together, these components provide an integrated application development platform that enables business and } \\
\text { IT to collaborate throughout the development life cycle. }\end{array}$ \\
\hline Appian & $\begin{array}{l}\text { Appian is a model-driven application development platform that enables IT and citizen developers to construct } \\
\text { process-centric and case-centric applications, continually improve processes, support intelligent business processes } \\
\text { and dynamically alter processes in response to digital business moments. The following analysis refers to Appian v.7.11. }\end{array}$ \\
\hline Bizagi & $\begin{array}{l}\text { Bizagi is one of the new entrants in this year's Magic Quadrant, positioned as the only vendor in the Challengers } \\
\text { quadrant. Bizagi, one of the oldest BPM vendors around, can claim this position because of its global customer } \\
\text { base, excellent execution capabilities and its disruptive business model based on "freemium" software. This } \\
\text { analysis pertains to Bizagi Modeler } 3.0 \text { and Bizagi Studio } 10.7 \text {. }\end{array}$ \\
\hline Pegasystems & $\begin{array}{l}\text { Pegasystems is the largest, best-known pure-play iBPMS vendor. Its iBPMS supports all usage scenarios } \\
\text { analysed in this Magic Quadrant. In the past two years, Pegasystems has ramped up its focus on digital business } \\
\text { transformation and mobile application development. This analysis is based on Pega v.7.1.9 and Pega Express. }\end{array}$ \\
\hline IBM & $\begin{array}{l}\text { IBM is enhancing the intelligence of its Smarter Process products through the use of complementary Watson } \\
\text { technologies, resulting in what it calls Cognitive Business Operations. It also improved cloud-based deployments } \\
\text { by enhancements in Blueworks Live and a licensing approach that allows customers to apply purchase credits to } \\
\text { either on-premises or cloud versions of BPM. }\end{array}$ \\
\hline Software AG & $\begin{array}{l}\text { Software AG historically placed a strong emphasis on BPM and application integration. In } 2015 \text {, it combined its } \\
\text { high-end webMethods BPMS product with its broad and deep middleware stack and newer analytic capabilities } \\
\text { to produce an integrated Digital Business Platform. This suite addresses a wide variety of on-premises and cloud- } \\
\text { based intelligent process and IoT business situations. }\end{array}$ \\
\hline
\end{tabular}

Source: compiled by the author on the basis of (Gartner, 2016) 
results of different business activities, which require continuous resource-alignment, workflow analysis, process optimization and budget control. In past days, business processes were supported by human resources due to the lack of technology such as machines, which were not interconnected together as there was no internet. In contrast, these days almost all devices are becoming smart and "internet of things" makes it possible to interconnect different sensors, smartphones, and workstations to a centralized access point or a central information system (Research Publish, 2016).

Here we will try to analyse the most progressive technological systems.

While iBPMSs can coordinate short-lived, transactional system-oriented processes, they are best used to manage long-lived business processes that span as people and systems, as well as functional boundaries. While some vendors use similar process execution engines, pure service-oriented architecture (SOA) orchestration is not a focus of an iBPMS.

Further, the mobile, social, cloud and analytics features in iBPMSs are more capable and better integrated than they were in 2015. Those solutions that balance ease of use and time to solution alongside greater intelligence capabilities are seeing the most success. Also essential are strong partner networks for business transformation capabilities (Gartner, 2016).

The rest of the paper is organized in the following way. Firstly, we shall consider in detail current situation in Ukrainian automobile market, and then we would contemplate the strength and weaknesses of Ukrainian economy for domestic automobile enterprises in terms of the European Union (EU) entering a period. In conclusion, we would try to provide references for future prospects and development of Ukrainian automobile market overall.

\section{The current situation in Ukrainian automobile market}

Since the beginning of the year, sales in Ukraine were at the level of 16,5 thousand units of the car. According to the ACEA, in March 2017, the auto market of the EU recorded an increase in sales of new cars by $11,2 \%$ in an annual comparison. A total of 1981583 cars were sold. According to the results of the first quarter of this year, the volume of sales of cars on the EU market grew by $8,4 \%$ compared to the same period last year to 4141269 units (ACEA, 2017).

The rate of the European automobile market growth (first quarter, 2017 year) indicated below.

\begin{tabular}{|c|c|}
\hline Country & Rate \\
\hline Italy & $12,6 \%$ \\
\hline Germany & $6,7 \%$ \\
\hline Great Britain & $6,2 \%$ \\
\hline France & 4,8 \\
\hline
\end{tabular}

Source: compiled by the author on the basis of (ACEA, 2017)
A number of cars sold by the European Automobile Giants in March 2017 indicated below.

\begin{tabular}{|c|c|c|}
\hline Automobile Giant & Amount, units & Rate \\
\hline Volkswagen & 403289 & $+6,5 \%$ \\
\hline Renault & 180481 & $+14,4 \%$ \\
\hline PSA & 178810 & $+6,9 \%$ \\
\hline Ford & 156523 & $+16,7 \%$ \\
\hline FCA & 129126 & $+17,7 \%$ \\
\hline Opel & 128702 & $+3,1 \%$ \\
\hline BMW & 126015 & $+7,7 \%$ \\
\hline Daimler & 111922 & $+12,7 \%$ \\
\hline
\end{tabular}

Source: compiled by author on the basis of (ACEA, 2017)

For a comparison, according to AUTO-Consulting, in March 2017 in Ukraine were sold 7 thousands of new cars with a dynamics of $+43 \%$ by March 2016 . Since the beginning of the year, the car market amounted to $\sim 16,5$ thousand new cars $(+35 \%)$.

In April, all the operators managed to sell 6,6 thousands of new cars, which is $17,25 \%$ more than a year ago. According to AUTO-Consulting, sales of new cars in Ukraine are growing for the 15 months in a row. Before that, a continuous increase in sales was observed from October 2010 to March 2012 - 18 months in a row (Auto-Consulting, 2017).

According to AUTO-Consulting, since January 2016, when sales for the first time showed a positive trend of $+19 \%$, in Ukraine, more than 80 thousand new cars were sold. At the same time, the maximum growth rates were observed in March $2016-+96 \%$, while the minimum growth of 5\% was recorded in July 2016. For the three months of 2017, the growth in sales of new cars was $35 \%$. The highest growth this year was demonstrated by January $-+54,5 \%$ compared to January last year. (AutoConsulting, 2017).

It should be noted that other segments of the Ukrainian car market also provide positive signals. In particular, the market for new LCVs (light commercial vehicles) has been growing since the beginning of the year $-+43 \%$. The market for new buses is growing for the 19 months in a row - from September 2015 to March 2017.

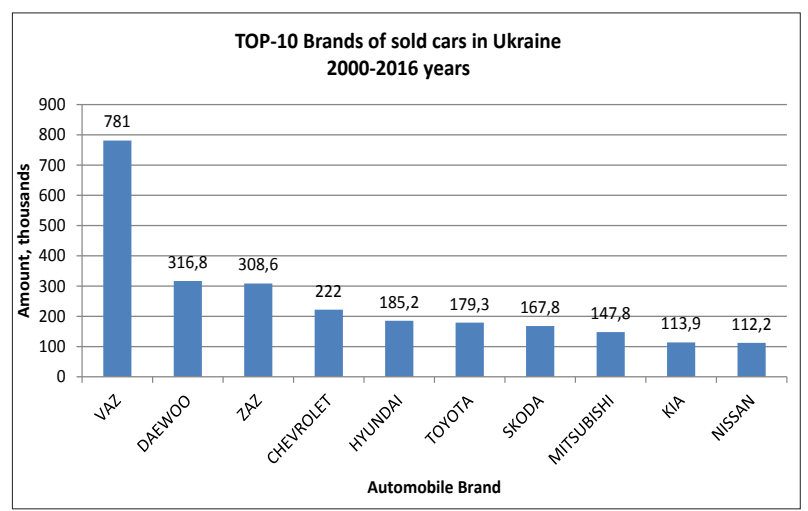

Source: compiled by the author on the basis of (Auto-Consulting, 2017) 
In the first quarter of this year, 39046 vehicles were imported to the territory of Ukraine under the import regime for \$588,5 million (UkrAutoProm, 2017).

The largest share in this import was a passenger car, the association "Ukrautoprom" reports. For three months importers spent $\$ 416,9$ million for the purchase of 28,9 thousand of passenger cars. Thus, compared to the same period last year, imports of cars increased by almost $80 \%$, and the outflow of currency for its purchase increased by $\$ 145,7$ million. At the same time, the average customs value of one imported car decreased by more than $\$ 2$ thousand compared to last years' indicator of $\$ 14,4$ thousand (UkrAutoProm, 2017).

\section{Strengths and weaknesses of Ukrainian economy for domestic automobile enterprises}

The urgency of reforming Ukraine's automotive industry is connected with political and economic challenges, which threaten the economic and social growth of the Ukraine, as well as with the need to implement the key provisions of the EU-Ukraine Association Agreement for facilitating erasing borders. Reforming this involves the introduction of a new ideology in the state administration for the development, local self-government and territorial organization of power in Ukraine based on the principle of small and middle business growth (Pysarenko, 2016).

While the recession, Ukraine's production declined more than sales. Some manufacturers have gone bankrupt (for example, the Kremenchug Automobile Plant in 2014, assembles and SsangYong Great Wall), and the rest have significantly reduced production volumes.

Automotive manufacturing is one of Europe's most enduring industrial activities, and it accounts for millions of jobs, billions of euros in investment, and represents a large portion of the continent's exports.

Keeping track of the extent of the automotive industry's activities, by providing regular and up-todate statistics is a key part of ACEA's mission. Accordingly, in this section, you will find data on global and European production, monthly registration

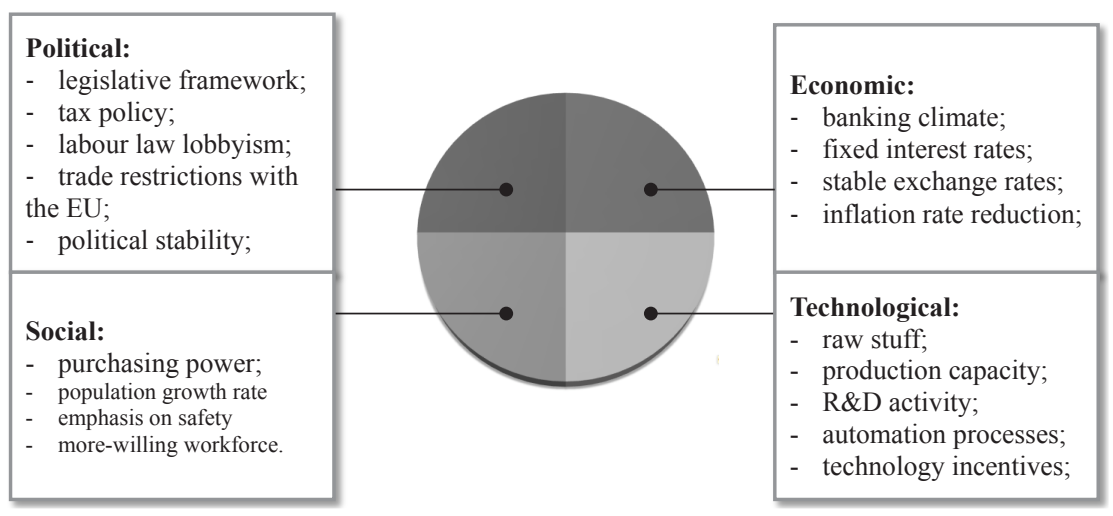

Source: compiled by the author on the basis of personal research figures for Europe, figures for employment and much more (ACEA, 2017).

As we can see on image below, Ukraine is the country with the lowest number of produced car in the World in 2016. Certainly, there were a lot of factors blocking domestic manufacturing, nevertheless, that is a real big problem.

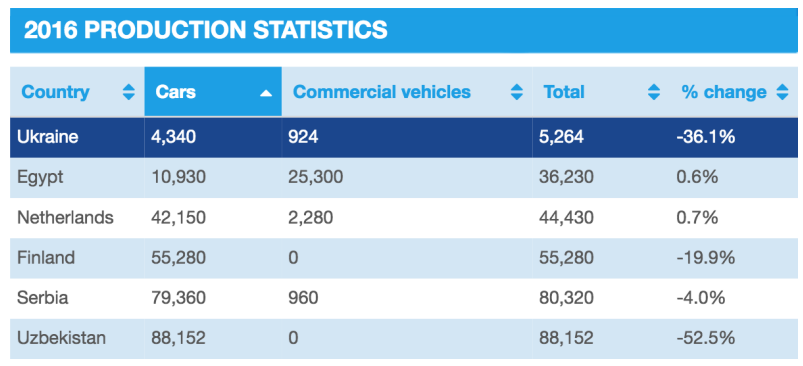

Source: compiled by the author on the basis of (OICA, 2017)

On the other rank below, we should observe the percentage rank going down by dynamic between 2016 and 2015. In this list, Ukraine ranks \#2 country with the highest negative exponent with $-36,1 \%$ boost, after Uzbekistan with $-52,5 \%$ boost. For reference, the \#1 growth rate is Iran with $+18,6 \%$, and Ukraine's neighbours - Czech Rep. (8,3\%), Poland (3,2), Russia $(-5,4 \%)$.

\begin{tabular}{|c|c|c|c|c|c|}
\hline \multicolumn{6}{|c|}{2016 PRODUCTION STATISTICS } \\
\hline Country $\triangleq$ & $\widehat{~ C a r s ~}$ & $\widehat{A}$ Commercial vehicles & $\Delta$ Total & $\widehat{\nabla}$ & $\%$ change $\triangle$ \\
\hline Uzbekistan & 88,152 & 0 & 88,152 & & $-52.5 \%$ \\
\hline Ukraine & 4,340 & 924 & 5,264 & & $-36.1 \%$ \\
\hline Finland & 55,280 & 0 & 55,280 & & $-19.9 \%$ \\
\hline Malaysia & 469,720 & 43,725 & 513,445 & & $-16.5 \%$ \\
\hline Taiwan & 251,096 & 58,435 & 309,531 & & $-11.8 \%$ \\
\hline Brazil & $1,778,464$ & 377,892 & $2,156,356$ & & $-11.2 \%$ \\
\hline
\end{tabular}

Source: compiled by the author on the basis of (OICA, 2017)

\section{Conclusions}

As we mentioned before, there are some pieces of advice how to make Ukrainian automobile market more competitive and to achieve business process improvement by embedding existing tools and opportunities for business optimization.

The first one is to Establish EcoInnovation Entrepreneurship.

On ownership structure, the Ukrainian auto companies are a mostly private enterprise (there are only 2 plants, one of them is a commercial automobiles plant), which makes entrepreneurs have most or even all of the enterprise property rights. An entrepreneur, who is both the owner of the business 
capital and decision-makers, attitude determines the effect of enterprise innovation activities. On the one hand, must strengthen the entrepreneurial innovation consciousness. On the other hand, entrepreneurs should strengthen the guidance of employees.

The second one step is to Sufficiently Grasp the Government Policy.

In the process of auto transformation, the government's policy is a very important external resource. At present in Ukraine, the national policy is conducive to the development of the Ukrainian Economic Belt automobile industry; automobile enterprises should fully grasp the government's policy to enhance their technological innovation capacity. Ecological economic policy requirements with industry ecological development and industrialization of ecological construction as the means, in order to renovation and advancement of traditional industries, development of new eco-industries, requiring the auto industry's traditional industries must be effectively transformed and upgraded.

The third one is to Strengthen the Input of Science and Technology Talents in Auto Industry.

With the increasing sophistication of technology and the development of competition for auto technology talent, especially senior personnel of more stringent requirements, not only to master the basic theory and professional knowledge in related fields but also master the relevant policies, proficient regulations and standards in their field, along with some technical tracking ability, practical ability, organizational skills, and coaching skills. An emphasis on investment of human resources, building bold innovation personnel is particularly critical. Done to improve the incentive mechanism and optimize the environment for the growth of talent; improve the training system, strengthening the effectiveness of training; build an innovative auto technology training model.

The fourth one is to Strengthen the IndustryUniversity-Institute Cooperation

Automobile industry's independent innovation enterprise efforts alone are not enough, also need to universities and scientific research institutions involved. First, it should be the formation of strategic alliances of industry-university-research. According to the current development level of economic and social of the Ukrainian Economic Belt, the number of universities and automobile specialties, the number of research institutions, and the level of innovation, to establish a scientific and reasonable benefits balanced mechanism and form a strategic alliance of industry-universityresearch. Second, industry-university-research parties clear division of labour. Universities do well in transport personnel and some basic research, research institutions do well in improving technological research, to provide theoretical and technical support, complete product trial; the company offers research and training funds to universities and research institutions, complete product development, bring the fruits of cooperation to the market (Liu, Yang, Enzhao Hu, 2016).

\section{References:}

ACEA - The European Automobile Manufacturers' Association [Electronic resource]. - Retrieved from: http://www.acea.be/statistics

Auto-Consulting - Since the beginning of the year, sales in Europe have exceeded 4 million new cars [Electronic resource]. - Retrieved from: http://www.autoconsulting.com.ua/article.php?sid=38630

Feng WEI, Wei-xiao ZHANG1, a, and Yong-yi QIN - Research on Transformation and Upgrading of the Xijiang Economic Belt Automobile Industry Based on the Eco-innovation Perspective [Electronic resource]. - Retrieved from: http://www.dpi-proceedings.com/index.php/dtssehs/article/viewFile/3499/3149

Integra-Co - Magic Quadrant for Intelligent Business Process Management Suites [Electronic resource]. Retrieved from: http://www.integra-co.com/sites/default/files/Bizagi\%20on\%20Gartner\%20Quadrant\%20\%20Reprint.pdf

ISO - Quality management systems -- Fundamentals and vocabulary [Electronic resource]. - Retrieved from: https://www.iso.org/standard/45481.html

John Brunswick, "Extending the Business Value of SOA through Business Process Management," Oracle, September 2008. [Electronic resource]. - Retrieved from: http://www.oracle.com/technetwork/articles/bpmand-soa-097534.html. [Accessed 14 March 2016].

Juric, Matjaz B., and Kapil Pant, usiness process driven SOA using BPMN and BPEL: from business process modeling to orchestration and service oriented architecture, Packt Pub, 2008.

KPMG 2016 LLP, Turn business processes into business advantages [Electronic resource]. - Retrieved from: https://home.kpmg.com/content/dam/kpmg/us/pdf/kpmg-and-ibm-smarter-process-solutions10-17.pdf

Liu, Yang, Enzhao $\mathrm{Hu}$, and Xudong Chen, "Architecture of information system combining SOA and BPM," Information Management, Innovation Management and Industrial Engineering, vol. 1, no. ICIII'08. International Conference on, 2008.

Organisation Internationale des Constructeurs d'Automobiles (OICA) - Production statictics [Electronic resource]. - Retrieved from: http://www.oica.net/category/production-statistics/

Pysarenko - Main directions of reforming the regional policy in Ukraine [Electronic resource]. - Retrieved from: http://rcin.org.pl/Content/61354/WA51_80457_r2016-t30_Europa-XXI-Pysarenko.pdf 
Research Publish - Business Process Optimization through SOA and Cloud [Electronic resource]. - Retrieved from: pdf\&act=book.

http://www.researchpublish.com/download.php?file=Business\%20Process\%20Optimization-3536.

UkrAutoProm - According to the results of the first quarter, imports of passenger cars increased by almost 80 percent [Electronic resource]. - Retrieved from: http://ukrautoprom.com.ua/en/po-itogam-i-kvartala-importlegkovyx-avto-vyros-na-80-procentov

Weske, Mathias, "Introduction," in Business process management: concepts, languages, architectures, Second ed., Springer Science \& Business Media, 2012, p. 5.

\section{Александр ПИДМУРНЯк}

ОПТИМИЗАЦИЯ БИЗНЕС-ПРОЦЕССОВ НА АВТОМОБИЛЬНЫХ ПРЕДПРИЯТИЯХ УКРАИНЫ В УСЛОВИЯХ ИНТЕГРАЦИИ С ЕС

Аннотация. Целью работы является обобщить и представить общие принципы и методы управления менеджментом для поиска наиболее эффективного и выгодного выхода для автомобильных предприятий в период экономического подъема в Украине. В ходе исследований мы проанализировали, что такое SOA (Service Oriented Architecture) и преимущества ее реализации, различия между ВРМ и IBPM (Intelligent Business Process Management Suite) и другие. Методика. Исследование основано на сравнении различных подходов к бизнесу и управлению, благодаря чему эффективность бизнес-процесса достаточно возрастает. Всего было проанализировано более 30 методов, в которых рассмотрено около 15 наиболее часто используемых систем управления, в результате чего было предложено 5 основных рекомендаций. Результаты исследования показали, что в Украине очень «туманная» социальная и политическая обстановка, человеческий капитал неразвит и менее меритократический, чем у наших соседей в ЕС. Недостаток отечественного производства автомобилей, отсутствие новых заводов и технологий, в результате чего количество рабочих мест остается неизменным или снижается из-за эмиграции, что приводит к росту количества импортируемых автомобилей. В попытках выявления самых актуальных угроз, мы обнаружили, что нет никаких государственных программ, грантов, лабораторий и научных заводов для молодого поколения. Практические значение. Поскольку Украина находится в состоянии войны, экономического и политического кризиса, обвала национальной валюты и другого, внутренние домохозяйства столкнулись с огромным количеством проблем: инфляция, нестабильный валютный курс, политическая неопределенность. Все это приводит к тому, что у отечественного бизнеса есть только один выход - это, искать варианты повышение роста эффективности управления и организационных преобразований на микроуровне. Значение/оригинальность. Метод управления компанией Agile - один из новейших методов оптимизации бизнес-процессов, который может осуществляться через такие приложения как: IBM, SoftwareAG, PegaSystems, AgilePoint. 